\title{
Effect of Enzymatic Hydrolysis on Polylactic Acid Fabrics by Lipases from Different Origins
}

\author{
So Hee Lee $\cdot$ Wha Soon Song ${ }^{\dagger}$ \\ Dept. of Clothing \& Textiles, Sookmyung Women's University \\ Received May 30, 2012; Revised June 20, 2012; Accepted June 21, 2012
}

\begin{abstract}
This study measured the effect of general pre-treatment on PLA fabrics to confirm the benefits of enzymatic processing on PLA fabrics in the textile industry as well as evaluated the hydrolytic activities of three lipases. The effects of lipase hydrolysis were analyzed through moisture regain, dyeing ability, tensile strength, and surface morphology. As a result, PLA fibers were easily damaged by a low concentration of sodium hydroxide and a low treatment temperature. The optimal treatment conditions of Lipase from Candida cylindracea were $\mathrm{pH} 8.0,40^{\circ} \mathrm{C}$, and $1,000 \mathrm{U}$. The optimal treatment conditions for Lipase from Candida rugosa were $\mathrm{pH} 7.2$, $37^{\circ} \mathrm{C}$, and $1,000 \mathrm{U}$. The optimal treatment conditions for Lipase from Porcine pancreas were $\mathrm{pH} 8.0,37^{\circ} \mathrm{C}$, and 2,000 U. The moisture regain and dyeing ability of PLA fabrics increased and the tensile strength of PLA fabrics decreased. The results of surface morphology revealed that there were some cracks due to hydrolysis on the surface of the fiber.
\end{abstract}

Key words: Polylactic acid, PLA, Lipase, Finishing, Enzymatic treatment

\section{Introduction}

Recently, development of new sources of power, as well as replacement of many fuels and chemicals products of petroleum with products of biomass is being carried out by employing biotechnology using plants, wood, manure, and microorganisms (Kamm \& Kamm, 2004, Kamm et al., 2008). In the textile industry, environmental materials are highlightened as a new insight of eco-friendly. Polylactic acid (PLA), which is linear aliphatic thermoplastic polyester made up of lactic acid (2-hydroxy propionic acid) building blocks or derived from $100 \%$ renewable resources such as corn (Drumright et al., 2000; Farrington et al., 2005), has received a considerable attention as a

\footnotetext{
${ }^{\dagger}$ Corresponding author

E-mail: doccubi@sm.ac.kr

This research was supported by Basic Science Research Program through the National Research Foundation of Korea (NRF) funded by the Ministry of Education, Science and Technology (NRF-2009-0066952).
}

biomass material in the textile industry. PLA is highly marketable due to the low unit cost of its raw materials, it is available from renewable agricultural resources, and it is biodegradable. Therefore, with the ongoing development and manufacture of various types of PLA fibers such as nonwoven, woven, and knit fabrics (Lee \& Song, 2011a; Sawada et al., 2007; Steinbüchel, 2002), PLA has the potential to replace conventional petrochemical-based polymers in the textile industry (Lee \& Song, 2011b).

Most studies on PLA fibers have focused on plastics, sheets, or films replacing PET or PTT in the textile industry (Drumright et al., 2000; Farrington et al., 2005; Oksman et al., 2003). However, there were a few researches of PLA fabrics for using clothing materials because its resistance to hydrolysis is not as good as that of synthetic fibers such as polyester, nylon, and PP (Drumright et al., 2000). Therefore, PLA fibers must be handled carefully during the dyeing and finishing of the fiber. In the textile industry, pretreatment processing such as desizing, scouring, 
or bleaching is required to improve such properties as dyeing absorption and hydrophilicity of fabrics. However, chemical processing methods may not be appropriate for PLA fibers due to their low resistance to chemicals. Therefore, to maximize the properties of PLA fibers and to minimize fiber damage, it is necessary to explore environmentally friendly processing procedures from manufacturing to finishing. Such procedures will help to increase the usefulness of value-added PLA fibers.

One of the more popular eco-friendly processing methods used in the textile industry is enzymatic-finishing processing (Lee et al., 2009). Enzymatic processing has been proposed and introduced as a biotechnology because it can be performed using existing equipment, which will equate to lower cost, lower energy use, and decreased water pollution (Akin et al., 2002; Aly et al., 2004; Avérous, 2002; Cavaco-Paulo, 1998; Guebitz \& Cavaco-Paulo, 2008; Lee et al., 2010; Sawada et al., 2007). Moreover, hydrolysis by enzymes normally occurs only on the fiber surface without affecting the chemical structure of the fiber, thus the fiber's properties can be maintained (Lee et al., 2010). Therefore, to apply PLA fibers in the textile industry, studies should be done on the beneficial effects of enzymatic treatment of PLA fibers. There has been no comprehensive article published yet on the improvement of the properties of PLA fibers due to enzyme hydrolysis. Also, the benefits of enzymatic processing in the textile industry must be confirmed.

Therefore, the purpose of this study is to evaluate the effect of desizing and alkaline treatment as a pretreatment of PLA fabrics. In addition, to judge the suitability of those steps for PLA fabrics, the effects were evaluated through the weight loss, tensile strength, and surface morphology. Moreover, to find suitable methods for PLA fabrics, the hydrolytic activity of three lipases was measured. Lipase is known for hydrolysis of ester bonds on PLA fiber. Thus, in this study, we chose three lipases which were shown the best activity in enzyme screening. And then, the benefits of enzymatic processing of PLA fabrics in the textile industry were evaluated through the moisture regain, dye exhaustion, tensile strength, and surface morphology.

\section{Experimental Details}

\section{Materials}

Huvis Korea supplied $100 \%$ polylactic acid (PLA) yarn with 75 denier of 72 filament of DTY-type. PLA fabrics were woven for the experiment under the conditions shown in $<$ Table $1>$ and with the properties displayed in $<$ Table $2>$.

Hydrogen peroxide (Duksan Pure Chemicals, Korea), sodium hydroxide (Duksan Pure Chemicals, Korea), Triton X-100 (Sigma Chemicals Co., USA), sodium carbonate (Duksan Pure Chemicals, Korea), and dodecylbenzenesulfonic acid sodium salt 50\% (LAS, Junsei Chemicals, Japan) were used for fabric desizing. Sodium hydroxide was used as an alkaline agent. Tris (hydroxymethyl) amino methane $\left(\mathrm{pKa}=8.06\right.$ at $20^{\circ} \mathrm{C}$, Sigma Chemical Co., USA) and sodium phosphate ( $\mathrm{pKa}=7.2$, Sigma Chemical Co., USA) were used as buffers for enzymes. Ethyl alcohol (Duksan Pure Chemicals, Korea) was used for inactivation of the microbial of the samples. Eight commercial lipases from different sources were used for this study (Table 3).

\section{Methods}

\section{1) Desizing}

Desizing of the PLA fabrics was carried out with use of oxidation hydrolysis, hot water, nonionic surfactant, and anionic surfactant treatment. Hydrogen peroxide $15 \mathrm{~g} / \mathrm{L}$ was used, and sodium hydroxide $2 \mathrm{~g} / \mathrm{L}$

Table 1. Characteristics of fabrics

\begin{tabular}{c|c|c|c|c}
\hline \hline $\begin{array}{c}\text { Fabric } \\
(\%)\end{array}$ & $\begin{array}{c}\text { Yarn count } \\
(\text { denier })\end{array}$ & $\begin{array}{c}\text { Fabric count } \\
(\text { unit yarn/cm })\end{array}$ & $\begin{array}{c}\text { Weight } \\
\left(\mathrm{g} / \mathrm{m}^{2}\right)\end{array}$ & $\begin{array}{c}\text { Thickness } \\
(\mathrm{mm})\end{array}$ \\
\hline PLA 100 & 75 & $35 \times 27$ & 56.83 & 0.132 \\
\hline
\end{tabular}

Table 2. Properties of PLA fabrics

\begin{tabular}{c|c|c}
\hline \hline \multicolumn{2}{|c|}{} & PLA \\
\hline \multicolumn{2}{c}{ Melting Point $\left({ }^{\circ} \mathrm{C}\right)$} & 167.9 \\
\hline \multirow{2}{*}{ Tensile Force (N) } & Warp & 151 \\
\cline { 2 - 3 } & Weft & 197 \\
\hline \multirow{2}{*}{$\begin{array}{c}\text { Elongation at } \\
\text { Max. Force (\%) }\end{array}$} & Warp & 32.9 \\
\cline { 2 - 3 } & Weft & 30.6
\end{tabular}

From Farrington et al. (2005). p. 198. 
Table 3. Properties of enzymes

\begin{tabular}{|c|c|c|c|c|}
\hline Source & Abbrev. & Activity & Form & Manufacturer \\
\hline C.cylindracea & LCC & $2 \mathrm{U} / \mathrm{mg}$ & Powder & Fluka \\
\hline C. rugosa & LCR & $700 \mathrm{U} / \mathrm{mg}$ & Powder & Sigma \\
\hline H. pancreas & LHP & $15-35 \mathrm{U} / \mathrm{mg}$ & Powder & Fluka \\
\hline K. lactic & LKL & $3,000 \mathrm{U} / \mathrm{ml}$ & Liquid & Sigma \\
\hline P. Stutzeri & $\mathrm{TL}$ & $50,000 \mathrm{U} / \mathrm{g}$ & Powder & Meito Sangyo \\
\hline $\begin{array}{c}\text { Alcaligenes } \\
\text { sp. }\end{array}$ & PL & $100,000 \mathrm{U} / \mathrm{g}$ & Powder & Meito Sangyo \\
\hline P. pancreas & LPP & $30-90 \mathrm{U} / \mathrm{g}$ & Powder & Sigma \\
\hline $\begin{array}{c}\text { Alcaligenes } \\
\text { sp. }\end{array}$ & PLG & $100,000 \mathrm{U} / \mathrm{g}$ & Powder & Meito Sangyo \\
\hline
\end{tabular}

was used for the oxidation hydrolysis of each fabrics. In addition, $2 \mathrm{~g} / \mathrm{L}$ nonionic surfactant and anionic surfactant was used. All treatment was performed at $80^{\circ} \mathrm{C}$ for $30 \mathrm{~min}$.

\section{2) Alkaline Treatment}

PLA fabrics were treated with sodium hydroxide that had a liquor ratio of 100:1 at $150 \mathrm{rpm}$ using a shaking water bath (BS-21, Jeio Tech., Korea). All samples were treated at various conditions of temperature $\left(40-80^{\circ} \mathrm{C}\right)$ and sodium hydroxide concentration (1-20\%) for $30 \mathrm{~min}$.

\section{3) Enzyme Screening}

For enzyme screening, eight lipases from different origins were used (Mayumi et al., 2008; Tokiwa \& Jarerat, 2004). Screening was carried out at optimal enzyme $\mathrm{pH}$ and temperature $<$ Table $4>$ with $1000 \mathrm{U}$

Table 4. Treatment conditions of various enzyme treatments

\begin{tabular}{c|c|c|c}
\hline \hline No & Enzyme & $\mathrm{pH}$ & Temperature $\left({ }^{\circ} \mathrm{C}\right)$ \\
\hline 1 & LCC & 8.0 & 40 \\
\hline 2 & LCR & 7.2 & 37 \\
\hline 3 & LHP & 8.0 & 37 \\
\hline 4 & LKL & 7.4 & 50 \\
\hline 5 & TL & $7-8$ & 50 \\
\hline 6 & PL & $8-9.5$ & 50 \\
\hline 7 & LPP & 8.0 & 37 \\
\hline 8 & PLG & $8-9.5$ & 50 \\
\hline
\end{tabular}

$\overline{\mathrm{pH}}$ and temperature information is provided by the manufacturer. per gram for $1 \mathrm{~h}$. All fabrics were treated at $180 \mathrm{rpm}$ using a shaking water bath (BS-21, Jeio Tech., Korea). The treated fabrics were washed and dried at room temperature. The most effective enzyme was determined through an examination of the weight loss.

\section{4) Enzymatic Treatment}

All enzymatic treatment on PLA fabrics was performed in a $50 \mathrm{mM}$ buffer using a liquor ratio of 100:1. Each hydrolytic activity was measured at a different enzyme concentration and the treatment time at the optimal $\mathrm{pH}$ and temperature of the enzyme. PLA fabrics were treated with three lipases selected through enzyme screening at $150 \mathrm{rpm}$ using a shaking water bath (BS-21, Jeio Tech., Korea). Following treatment, the residual enzyme of all the treated samples was inactivated and denatured with $70 \%$ of ethanol. After inactivation, the samples were thoroughly washed by sonication for $15 \mathrm{~min}$, washed with distilled water at a liquor ratio of 100:1, and then dried at room temperature.

\section{5) Weight Loss}

The weight loss of PLA fabrics was evaluated by measuring the dry weight of the fabrics. The samples were dried in a conventional dry oven at $105^{\circ} \mathrm{C}$ for $90 \mathrm{~min}$ and then weighed in a closed weighing bottle after being cooled in an automatic desiccator. The weight loss percentage was calculated as follows;

$$
\text { Weight loss }(\%)=\frac{\mathrm{W}_{1}-\mathrm{W}_{2}}{\mathrm{~W}_{1}} \times 100 \quad \cdots . \text { Eq. } 1 .
$$

where $\mathrm{W}_{1}$ and $\mathrm{W}_{2}$ are the dry weights of the fabrics before and after treatment, respectively.

\section{6) Moisture Regain}

Moisture regain was measured in accordance with ASTM D 629-99 by comparing the dry weight and moisture conditioning weight of enzyme-treated PLA fabrics. Samples were dried in an oven at $105^{\circ} \mathrm{C}$ for $1 \mathrm{~h}$ and then weighed after cooling in a desiccator for $30 \mathrm{~min}$. Moisture conditioning was carried out at $20^{\circ} \mathrm{C}$ and $65 \%$ relative humidity for $24 \mathrm{~h}$. The moisture regain was calculated using the following equation: 


$$
\text { Moisture regain }(\%)=\frac{\mathrm{W}_{\mathrm{m}}-\mathrm{W}_{\mathrm{d}}}{\mathrm{W}_{\mathrm{d}}} \times 100 \quad \cdots . \text { Eq. } 2 .
$$

where $\mathrm{W}_{\mathrm{m}}$ is the weight of fabric in moisture equilibrium state at $20^{\circ} \mathrm{C}$ and $65 \%$ relative humidity, and $\mathrm{W}_{\mathrm{d}}$ is weight of fabric dried at $105^{\circ} \mathrm{C}$ for $90 \mathrm{~min}$.

\section{7) Dyeing Property}

Dyeing property is evaluated by dye exhaustion. Disperse dye (C.I. Disperse blue 56) with lower energy level type was used. PLA fabrics dyed with $0.5 \%$ (owf) of disperse dye concentration, 30:1 of liquor ratio at $110^{\circ} \mathrm{C}$ for $60 \mathrm{~min}$ using Infrared ray dyeing machine (Starlet-2, Daelim Starlet Co. LTD., Korea). The absorbances of each dye bath both before and after exhaustion was measured at $560 \mathrm{~nm}$ using a spectrophotometer using UV-Vis spectrophotometer (M-3000, Scinco Co. Ltd., Korea). The percentage of exhaustion of each dye on PLA fabrics was calculated as follows:

$$
\text { Exhaustion }(\%)=\frac{\mathrm{C}_{0}-\mathrm{C}_{1}}{\mathrm{C}_{0}} \times 100 \quad \cdots . \text { Eq. } 3 .
$$

Where $\mathrm{C}_{0}$ is the dye absorbance in the dye bath before dyeing, $\mathrm{C}_{1}$ is that after dyeing.

\section{8) Tensile Strength}

The tensile strength of the untreated, alkaline-treated, and enzyme-treated fabrics was determined using a digital tensility strength tester (ASA-211-1, Asia Testing Machines CO., Korea) by the strip method according to KS K 0521. An average of five test runs was reported.

\section{9) Surface Morphology}

The surface morphology of the fabrics was analyzed using a scanning electron microscope (SEM, S-4800, Hitachi, Japan) after the samples were plated with osmium.

\section{Results and Discussion}

\section{Pretreatment}

\section{1) Desizing}

In this experiment, PVA-acrylic was used as a sizing agent for weaving PLA fabrics. To apply post-processing, the desizing process is necessary. Therefore, we investigated suitable desizing methods for PLA fabrics by comparing several desizing methods. Generally, the PVA-acrylic agent was removed by treating with hydrogen peroxide with sodium hydroxide, nonionic surfactant with sodium carbonate, nonionic surfactant, or anionic surfactant. It can also be removed with warm or hot water (Kadolph, 2004). Therefore, we evaluated the effects of those desizing methods.

$<$ Fig. $1>$ shows the weight loss of PLA fabrics depending on different desizing methods. PLA fabrics had $6.1 \%$ weight loss when treated with hydrogen peroxide with sodium hydroxide, $2.3 \%$ weight loss when treated with Triton X-100 with sodium carbonate, and $0.5-0.7 \%$ weight loss when treated with warm water, hot water, nonionic surfactant, and anionic surfactant. When PLA fabrics were woven, a sizing agent was added at about $0.5-1.0 \%$. As a result, we expected that desizing would be completed by all the above methods, and some fiber damage would result after treatment with hydrogen peroxide and sodium carbonate.

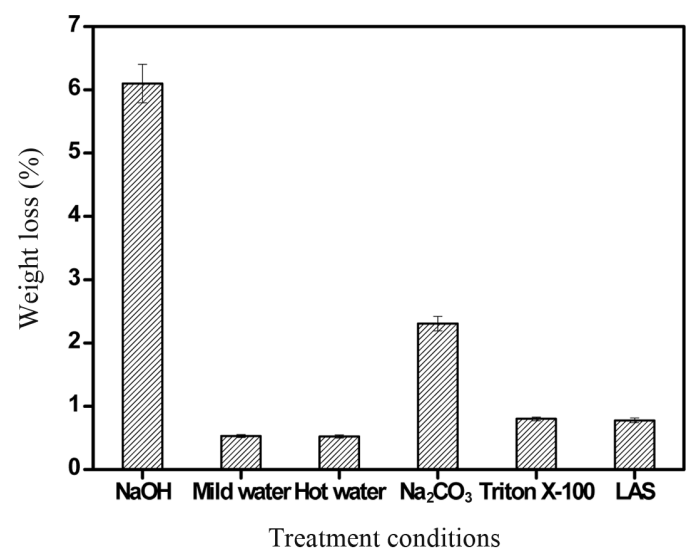

$\mathrm{NaOH}: 15 \mathrm{~g} / \mathrm{L}$ of hydrogen peroxide $+2 \mathrm{~g} / \mathrm{L}$ of sodium hydroxide at $80^{\circ} \mathrm{C}$ water

Hot water: $80^{\circ} \mathrm{C}$ water

Warm water: $50^{\circ} \mathrm{C}$ water

$\mathrm{Na}_{2} \mathrm{CO}_{3}: 1 \mathrm{~g} / \mathrm{L}$ of sodium carbonate $+1 \mathrm{~g} / \mathrm{L}$ of Triton X-100 at $80^{\circ} \mathrm{C}$ water

Triton X-100: $1 \mathrm{~g} / \mathrm{L}$ of Triton $\mathrm{X}-100$ at $80^{\circ} \mathrm{C}$ water

LAS: $1 \mathrm{~g} / \mathrm{L}$ of LAS at $80^{\circ} \mathrm{C}$ water

Fig. 1. Weight loss of desized PLA fabrics depending on different method (Treatment time: $\mathbf{3 0} \mathrm{min}$.). 
As shown in $<$ Fig. $1>$, PLA fabrics were desized by warm water without any chemicals. Thus, to desize PLA fabric, nonionic surfactant and anionic surfactant are not essential. Therefore, a suitable desizing method for PLA fabrics is treatment with warm water.

$<$ Fig. $2>$ shows the tensile strength of PLA fabrics depending on different desizing methods. As shown in the $<$ Fig. $2>$, approximately 1.08 -fold (7.0\%) and 1.04 -fold $(3.8 \%)$ decrease in the tensile strength of PLA fabrics was observed when treated with hydrogen peroxide with sodium hydroxide and nonionic surfactant with sodium carbonate, respectively. However, when treated with warm water, hot water, nonionic surfactant, and anionic surfactant, the loss of tensile strength was within $1.0 \%$. Therefore, in point of tensile strength, all desizing method was able to remove the sizing agent except to use of hydrogen peroxide solution or sodium carbonate.

$<$ Fig. $3>$ shows the surface morphology of PLA fabrics depending on different desizing methods. Before desizing, the sizing agent remained on the PLA $<$ Fig.

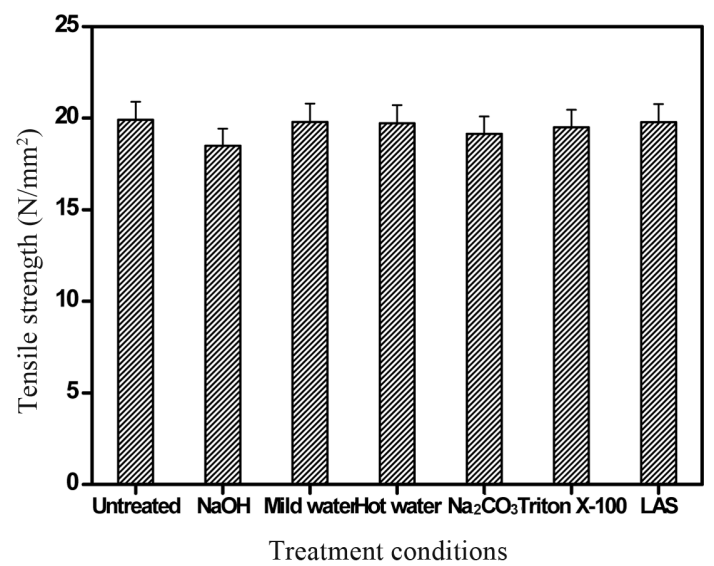

$\mathrm{NaOH}: 15 \mathrm{~g} / \mathrm{L}$ of hydrogen peroxide $+2 \mathrm{~g} / \mathrm{L}$ of sodium hydroxide at $80^{\circ} \mathrm{C}$ water

Hot water: $80^{\circ} \mathrm{C}$ water

Warm water: $50^{\circ} \mathrm{C}$ water

$\mathrm{Na}_{2} \mathrm{CO}_{3}: 1 \mathrm{~g} / \mathrm{L}$ of sodium carbonate $+1 \mathrm{~g} / \mathrm{L}$ of Triton X-100 at $80^{\circ} \mathrm{C}$ water

Triton X-100: $1 \mathrm{~g} / \mathrm{L}$ of Triton X-100 at $80^{\circ} \mathrm{C}$ water

LAS: $1 \mathrm{~g} / \mathrm{L}$ of LAS at $80^{\circ} \mathrm{C}$ water

Fig. 2. Tensile strength of desized PLA fabrics depending on different method (Treatment time: 30 min.).
$3>$ fabrics; however, after desizing, the sizing agent was clearly removed effectively from the PLA $<$ Fig. 3(A1) $>-<$ Fig. 3(A4) $>$ fabrics. When treated with hydrogen peroxide with sodium hydroxide $<$ Fig. 3(A1) $>$ and nonionic surfactant with sodium carbonate $<$ Fig. 3(A4)>, the sizing agent was removed clearly; however, some of the fiber surface was degraded, and some wrinkles were observed on the surface of the fiber. In other words, the fiber was damaged. When treated with nonionic surfactant with sodium carbonate $<$ Fig. 3(A4) $>$, some of the fiber was melted. When desized by warm water and hot water $<$ Fig. 3(A2) $>$ $<$ Fig. 3(A3) $>$, there was no fiber damage, and the sizing agent was removed perfectly.

From the results displayed in $<$ Fig. $1>-<$ Fig. $3>$, we could conclude that the use of hydrogen peroxide with sodium hydroxide and sodium carbonate results in some fiber damage, such as loss of weight and strength or cracks on the surface of the fiber. As shown by the results of the weight loss, tensile strength, and surface morphology, all desizing method were able to

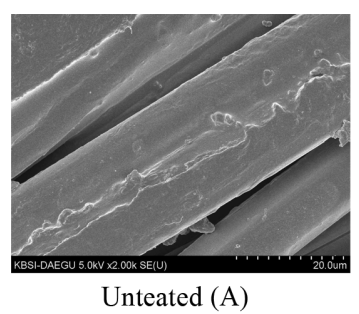

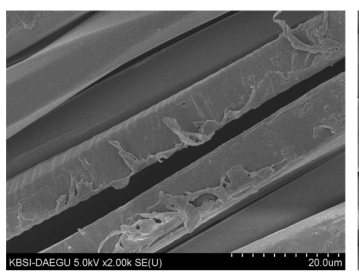

$\mathrm{H}_{2} \mathrm{O}_{2}+\mathrm{NaOH}(\mathrm{A} 1)$

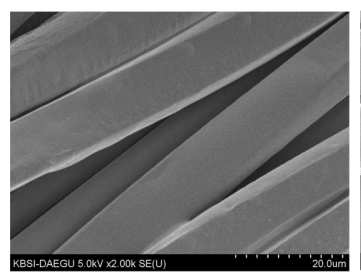

Hot water (A3)

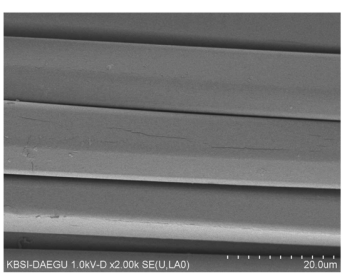

Warm water (A2)

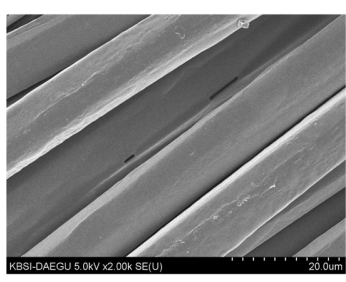

Triton $\mathrm{X}-100+\mathrm{Na}_{2} \mathrm{CO}_{3}(\mathrm{~A} 4)$
Fig. 3. SEM images of desized PLA fabrics (Treatment time: $30 \mathrm{~min}$.). 
remove the sizing agent; however, some fiber damage occurred from the use of hydrogen peroxide solution or sodium carbonate.

Taking into account all the conditions in this study, we desized the PLA fabrics using warm water as pretreatment processing.

\section{2) Alkaline Treatment}

$<$ Fig. $4>$ shows the weight loss of PLA fabrics after alkaline treatment depending on treatment temperatures from 40 to $60^{\circ} \mathrm{C}$ and alkaline concentrations from 1 to $20 \%(\mathrm{w} / \mathrm{v})$. The weight loss of PLA fabrics increased sharply with an increase in treatment temperature and alkaline concentration. Moreover, at over $10 \%$ of alkaline concentration, the loss of weight was $50 \%$ at all temperature, and all samples were degraded at $80^{\circ} \mathrm{C}$ of treatment temperature regardless of alkaline concentration. A weight loss within $30 \%$ only occurred at low temperatures such as 40 and $50^{\circ} \mathrm{C}$ and $5 \%$ alkaline concentration. In addition, treatment with $1 \%$ alkaline concentration resulted in $10 \%$ of weight loss at all temperatures. Therefore, PLA fiber can be affected by treatment temperature and alkaline concentrations, and treatment with $1 \%$ of alkaline concentration at low temperature is recommended.

$<$ Fig. 5 $>$ shows the tensile strength of PLA fabrics by alkaline treatment depending on treatment temperatures from 40 to $80^{\circ} \mathrm{C}$ and alkaline concentra-

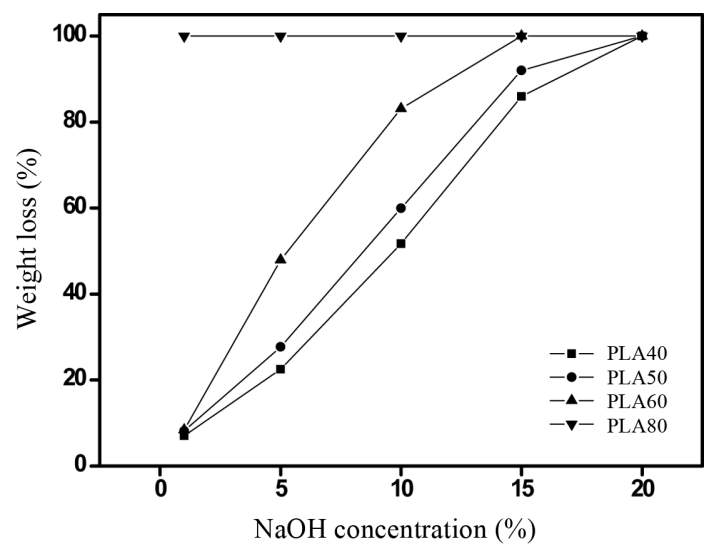

Fig. 4. Weight loss of sodium hydroxide treated PLA fabrics depending on different alkaline concentrations (Treatment conditions: $30 \mathrm{~min}$.). tions from 1 to $20 \%(\mathrm{w} / \mathrm{v})$. The tensile strength of PLA fabrics decreased sharply with increasing treatment temperature and alkaline concentration. Moreover, at $10 \%$ alkaline concentration, the loss of tensile strength was $100 \%$ at all temperatures. These aspects corresponded with the weight loss. In addition, PLA fabrics had $50 \%$ weight loss when treated with $10 \%$ alkaline concentration; however, that sample lost $100 \%$ of its tensile strength. Therefore, we confirmed that PLA fabrics could be influenced more easily by alkaline concentrations and treatment temperatures.

$<$ Fig. $6>$ indicates the surface morphology of PLA

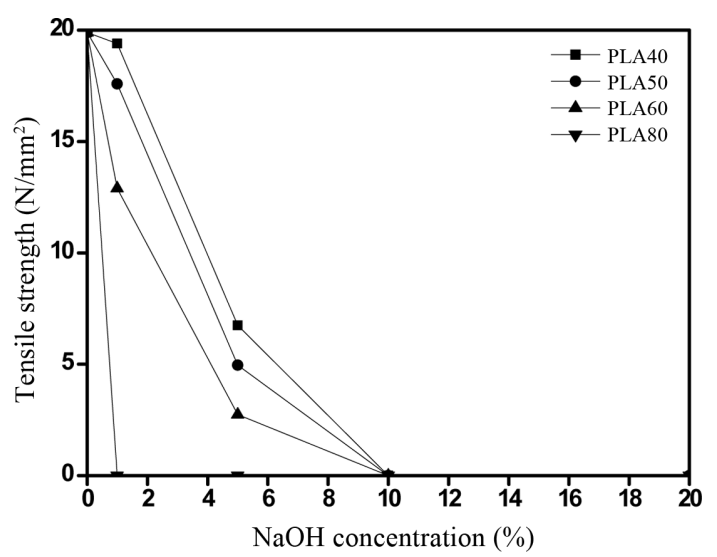

Fig. 5. Tensile strength of sodium hydroxide treated PLA fabrics depending on different alkaline concentrations (Treatment conditions: $30 \mathrm{~min}$.).

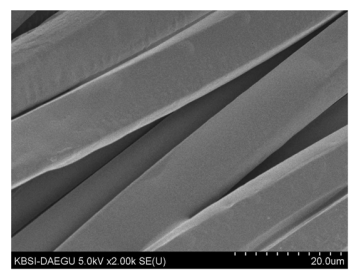

Untreated (A)

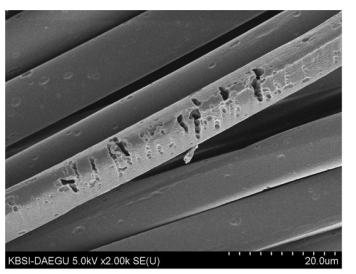

$5 \%\left(40^{\circ} \mathrm{C}\right)(\mathrm{A} 2)$

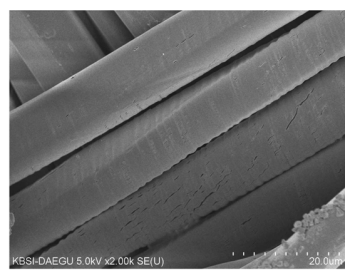

$1 \%\left(40^{\circ} \mathrm{C}\right)(\mathrm{A} 1)$

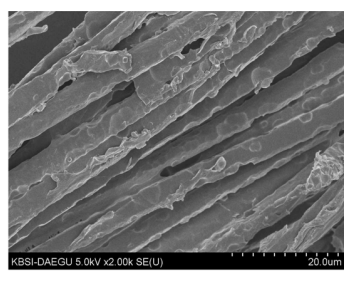

$5 \%\left(60^{\circ} \mathrm{C}\right)(\mathrm{A} 3)$
Fig. 6. SEM images of sodium hydroxide treated PLA fabrics (Treatment conditions: $30 \mathrm{~min}$.). 
fabrics by alkaline treatment depending on treatment temperatures from $40^{\circ} \mathrm{C}$ to $60^{\circ} \mathrm{C}$ and alkaline concentrations from $1 \%$ to $20 \%(\mathrm{w} / \mathrm{v})$. PLA fabrics treated with $1 \%$ of alkaline concentration at $40^{\circ} \mathrm{C}$ had some cracks (Fig. 6(A1)). When treated with $5 \%$ of alkaline concentration at $40^{\circ} \mathrm{C}$, having $22 \%$ of weight loss, depth cracks were observed on the fiber surface (Fig. 6(A2)). In addition, fiber surfaces and the inner part of the fibers were destroyed and broken at $60^{\circ} \mathrm{C}$ when treated with the same concentration (Fig. 6(A3)). In the case of fiber diameter, the diameter of untreated PLA fiber was about $23 \mu \mathrm{m}$; however, the diameter of PLA fiber treated with $5 \%$ alkaline concentration at $60^{\circ} \mathrm{C}$ was about $5.18 \mu \mathrm{m}$ (Fig. 6(A3)). That is, the size of the PLA filament decreased about fourfold by alkaline treatment.

As a result, we can conclude that mild conditions are recommended for PLA fabrics, thus alternative mild pretreatment processing such as enzyme processing is needed for PLA fabrics to improve fabric properties.

\section{Enzyme Screening}

$<$ Fig. $7>$ shows the results of enzyme screening of eight commercial lipases. To find the optimum enzyme for PLA fibers, we selected some lipases from different origins; they are known for hydrolysis ester groups of PLA fibers. Then, we evaluated the effect of enzyme hydrolysis through the weight loss at the optimum conditions of enzymes. As shown in $<$ Fig. $7>$, we selected lipase from Candida cylindracea,

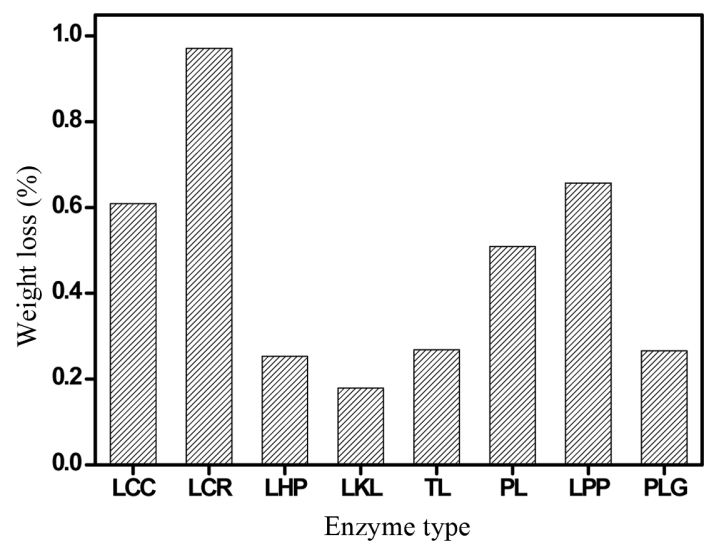

Fig. 7. Enzyme screening of PLA fabrics. lipase from Candida rugosa, and lipase from Porcine pancreas, which showed the highest enzyme activity for the next experiment.

\section{Enzyme Hydrolysis}

$<$ Fig. $8>$ shows the weight loss of three lipases on PLA fibers at the enzyme concentration from 100 to $8000 \mathrm{U}$ at optimal $\mathrm{pH}$ and temperature for $1 \mathrm{~h}$. The weight loss of LCC and LCR increased until $1000 \mathrm{U}$, and then over $1000 \mathrm{U}$ it decreased rapidly. The weight loss of LPP increased until $2000 \mathrm{U}$, and then showed some decrement. Hydrolytic activity depending on enzyme concentration is not stable because the enzyme reacts to the substrate and achieves equilibrium; however, some of the denatured enzyme protein produced coagulation in the solution when excess enzyme was used (Lee \& Song, 2010, 2011a). Overall, in this study, we discretized the LCC, LCR, and LPP concentration at 1000, 1000, $2000 \mathrm{U}$, respectively.

$<$ Fig. $9>$ indicates the weight loss of three lipases on PLA fibers in the enzyme treatment time from 30 to $480 \mathrm{~min}$ at optimal $\mathrm{pH}$, temperature, and enzyme concentration. The weight loss of LCC was about $1 \%$ when treated for $30 \mathrm{~min}$, and then decreased as time increased. It is confirmed that LCC was activated within initial $30 \mathrm{~min}$. The weight loss of LCR and LPP showed the highest value treated for 1 and $2 \mathrm{~h}$, respectively. Each enzyme's activity was decreased over the optimal treatment time. As treatment time increased, the weight loss of all three lipases increased

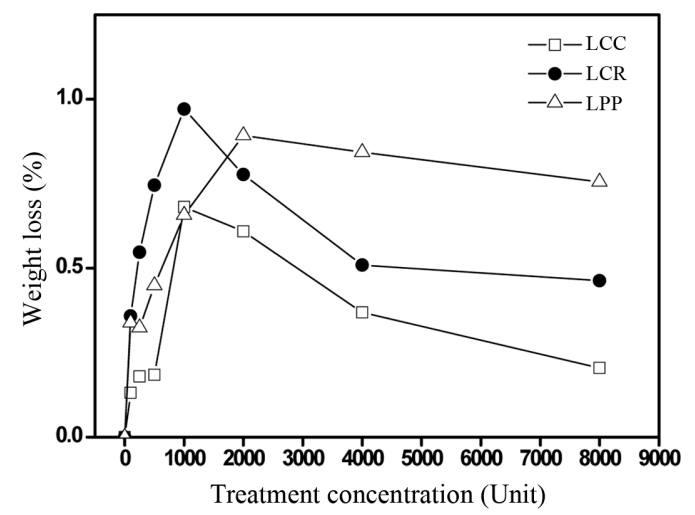

Fig. 8. Weight loss of enzyme treated PLA fabrics depending on treatment concentration. 


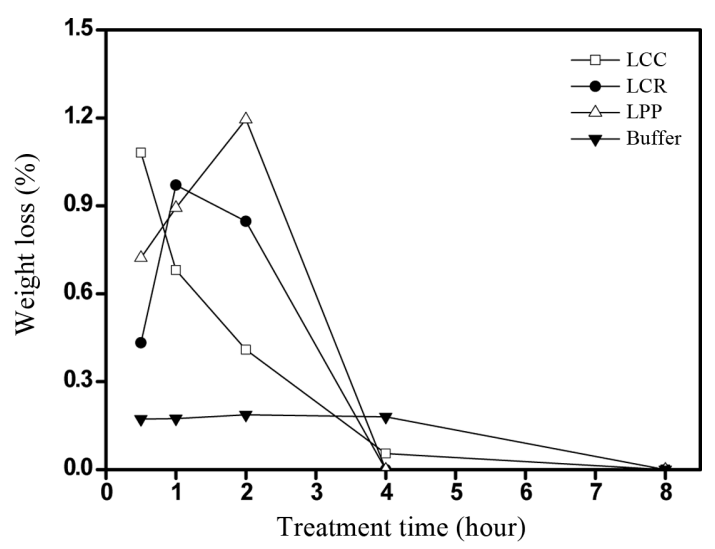

Fig. 9. Weight loss of enzyme treated PLA fabrics depending on treatment time.

unexpectedly since there was adsorption of the enzyme protein on the surface of fiber and it caused the activity cease (Lee \& Song, 2011b). Therefore, the optimal treatment time of LCC, LCR, and LPP is 30,60 , and $120 \mathrm{~min}$, respectively.

$<$ Fig. $10>-<$ Fig. $12>$ display the results of the moisture regain, the dyeing ability, and the tensile strength, and the surface morphology of lipase-treated fabrics at the optimal treatment conditions. Lipase hydrolysis on ester linkage cause producing hydroxyl and carboxyl groups on the surface of the fabrics, so surface hydrophilicity of PLA fabrics could be improved (Eberl et al., 2008; Hsieh \& Cram, 1998; Lee \& Song, 2010; Vertomen et al., 2005; Yoon et al., 2002). The moisture regain of untreated PLA fabric was about $0.8 \%$, and then increased about 1.25 -fold after lipase treatment (Fig. 10). In addition, compared to the relative moisture regain, LCR showed the largest value of the moisture regain compared with LCC and LPP, respectively. The increase in the moisture regain is due to the increase in hydrophilicity from hydrolysis of the surface of the fiber. The increase of moisture regain clearly indicates that hydroxyl and carboxyl groups were produced on the surface of PLA fabrics by broken ester linkages (Lee \& Song, 2010, 2011a, 2011b).

The dyeing ability of lipase-treated PLA fibers is shown in $<$ Fig. 11 $>$. The dyeing ability was measured at $595 \mathrm{~nm}$ by dye exhaustion. The dye exhaustion by lipase treatment was promoted as the polymer chain of

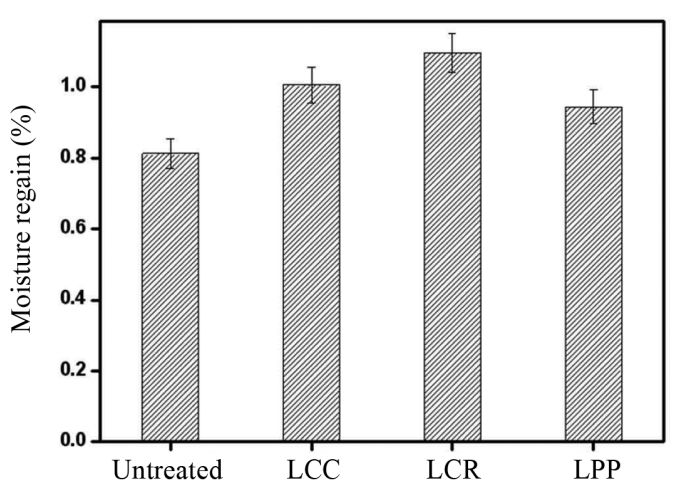

Fig. 10. Moisture regain of enzyme treated PLA fabrics.

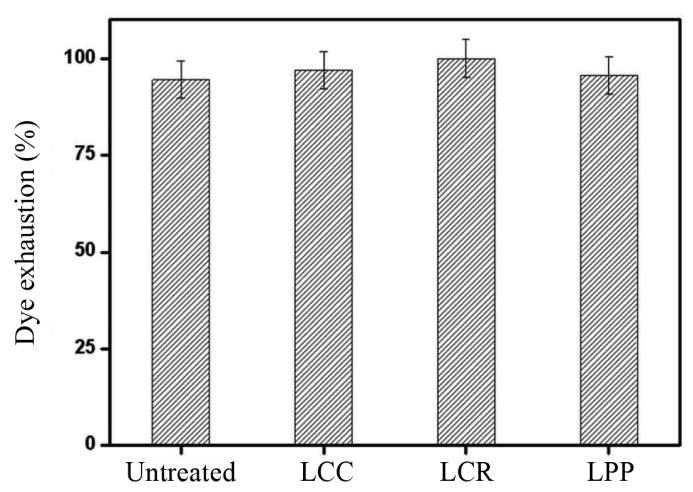

Fig. 11. Dye exhaustion of enzyme treated PLA fabrics.

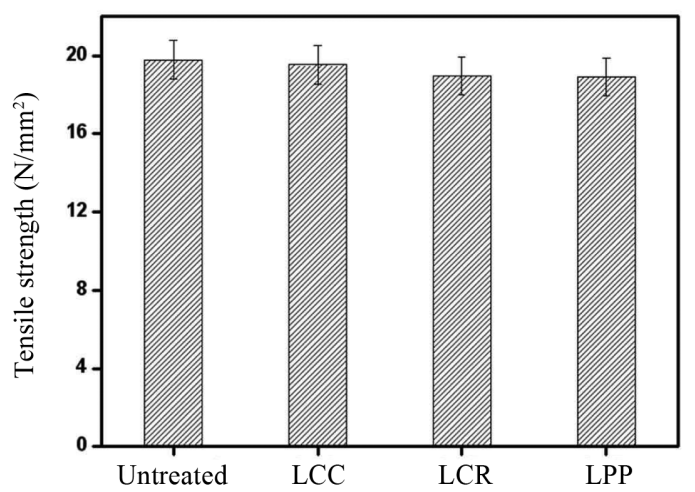

Fig. 12. Tensile strength of enzyme treated PLA fabrics.

PLA fibers was weakened and cleaved by enzymatic hydrolysis, the dye could permeate easily into the inner space of the fiber (Scheyer \& Chiweshe, 2001), 
the specific surface area increased due to enzyme hydrolysis, and the dye exhaustion was increased. The increase in dye exhaustion coincides with weight loss and moisture regain, and this confirmed that the increase in weight loss and moisture regain affects the improvement of dye exhaustion on PLA fibers.

$<$ Fig. $12>$ indicates the tensile strength of untreated and lipase-treated PLA fabrics. The tensile strength of PLA fabrics was decreased a little due to all lipase treatment. Especially, LCR, which has the highest loss of weight, moisture regain, dye exhaustion decreased largely compared with LCC and LPP. This is due to break of ester linkage of PLA fiber by enzymatic hydrolysis (Lee \& Song, 2010, 2011a, 2011b). However, as shown in $\langle$ Fig. 12 $>$, untreated and lipasetreated PLA fabrics showed similar tensile strength in a $95 \%$ confidence interval. Therefore, there was no fiber damage and physical properties were maintained by enzymatic hydrolysis.

$<$ Fig. 13 $>$ shows the surface morphology of PLA fibers treated with three lipases at the optimum hydrolytic activity conditions. As shown in $\langle$ Fig. 13 $>$, LCC treated fabrics shows some cracks on the fiber, In addition, LCR and LPP treated fabrics had micro cracks and micro pores were observed at the surface of the fibers. These micro cracks and micro pores could contain moistures so they provide strong evidence that some enzymatic hydrolysis occurs in the surface of PLA fiber and facilitate improvements in

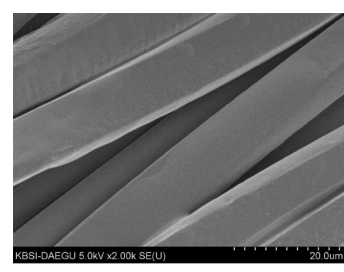

Untreated

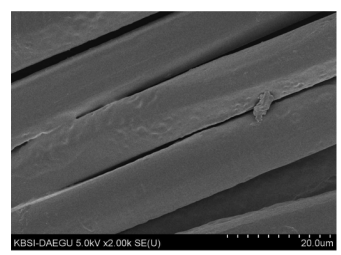

LCR

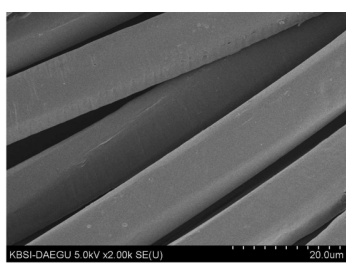

LCC

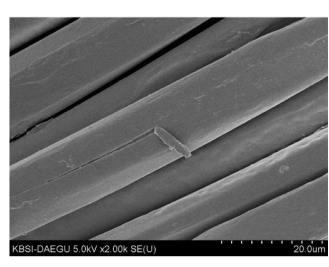

LPP
Fig. 13. SEM micrographs of enzyme treated PLA fabrics. the hydrophilicity of PET fabrics (Lee et al., 2009, Lee \& Song, 2010). That is, these cracks did not result in a decrease in the tensile strength of the fibers, but they did increase moisture regain and dyeing ability. Therefore, enzymatic processing with lipase is effective post-finishing which can maintain the fiber properties minimizing fiber damage.

\section{Conclusions}

In this study, the effect of general pre-treatment on PLA fabrics was measured to confirm the benefits of enzymatic processing on PLA fabrics in the textile industry and the hydrolytic activities of three lipases were evaluated. Moreover, the effects of lipase hydrolysis were analyzed through moisture regain, dyeing ability, tensile strength, and surface morphology. The results are follows:

1. PLA fibers were damaged easily by a low concentration of sodium hydroxide and low treatment temperature. Thus, alkaline treatment is not a suitable process for PLA pretreatment.

2. The optimal treatment conditions of LCC were a $\mathrm{pH}$ of 8.0 , a temperature of $40^{\circ} \mathrm{C}$, and an enzyme concentration of $1,000 \mathrm{U}$. The optimal treatment conditions for LCR were a $\mathrm{pH}$ of 7.2, a temperature of $37^{\circ} \mathrm{C}$, and an enzyme concentration of $1,000 \mathrm{U}$. The optimal treatment conditions for LPP were a $\mathrm{pH}$ of 8.0 , a temperature of $37^{\circ} \mathrm{C}$, and an enzyme concentration of $2,000 \mathrm{U}$.

3. The moisture regain and dyeing ability of PLA fabrics were increased by lipase treatment. Tensile strength of treated PLA fabrics was decreased a little after all lipase treatments. SEM images revealed that there were some cracks due to hydrolysis on the surface of the fiber.

4. Among three lipases, at the optimal treatment conditions, the moisture regain and dyeing ability is the highest when LCR-treated then LCC, LPP, in order.

\section{References}

Akin, D. E., Slomczynski, D., Rigsby, L. L., \& Eriksson, K. L. (2002). Retting flax with endopolygalacturonase from 
Rhizopus Oryzae. Textile Research Journal, 72(1), 27-34. Aly, A. S., Moustafa, A. B., \& Hebeish, A. (2004). Biotechnological treatment of cellulosic textiles. Journal of Cleaner Production, 12(7), 697-705.

Avérous, L. (2002). Polylactic acid: Synthesis, properties and applications. In M. Belgacem \& A. Gandini (Eds.), Monomers, polymers and composites from renewable resources (pp. 433-450). Amsterdam: Elsavier.

Drumright, R. E., Gruber, P. R., \& Henton, D. E. (2000). Polylactic acid technology. Advanced Materials, 12 (23), 1841-1846.

Eberl, A., Heumann, S., Kotek, R., Kaufmann, F., Mitsche, S., Cavaco-Paulo, A., \& Gübitz, G. M. (2008). Enzymatic hydrolysis of PTT polymers and oligomers. Journal of Biotechnology, 135(1), 45-51.

Cavaco-Paulo, A. (1998). Processing textile fibers with enzymes: An overview. In K. E. Erriksson \& A. CavacoPaulo (Eds.), Enzyme application in fiber processing (pp. 180-189). Washington D.C.: American Chemical Society.

Farrington, D. W., Lunt, J., Davies, S., \& Blackburn, R. S. (2005). Poly(lactic acid) fibers. In R. S. Blackburn (Ed.) Biodegradable and sustainable fibres (pp. 191-220). Cambridge: Woodhead Publishing Limited.

Guebitz, G. M., \& Cavaco-Paulo, A. (2008). Enzymes go big: Surface hydrolysis and functionalisation of synthetic polymers. Trends in Biotechnology, 26(1), 32-38.

Hsieh, Y. L., \& Cram, L. A. (1998). Enzymatic hydrolysis to improve wetting and absorbency of polyester fabrics. Textile Research Journal, 68(5), 311-319.

Kadolph, S. J. (2004). Textiles (11th ed.). New Jersey: Prentice Hall.

Kamm, B., \& Kamm, M. (2004). Principles of biorefineries. Applied Microbiology and Biotechnology, 64(2), 137145.

Kamm, B., Kamm, M., Gruber, P. R., \& Kromus, S. (2008). Biorefineries-industrial processes and products. In: B. Kamm, P. R. Gruber, \& M. Kamm (Eds.), Ullmann's encyclopedia of industrial chemistry (pp. 1-40). Weinheim: Wiley-VCH.

Lee, S. H., Kim, H. R., Lee, B. H., \& Song, W. S. (2010).
Enzymatic hydrolysis of chitosan fiber using cellulase and papain. Textile Science and Engineering, 47(3), 212-221.

Lee, S. H., \& Song, W. S. (2010). Surface modification of polyester fabrics by enzyme treatment. Fibers and Polymers, 11(1), 54-59.

Lee, S. H., \& Song, W. S. (2011a). Enzymatic hydrolysis of polylactic acid fiber. Applied Biochemistry and Biotechnology, 164(1), 89-102.

Lee, S. H., \& Song, W. S. (2011b). Hydrolysis of polylactic acid fiber by lipase from porcine pancreas. Journal of Korean Society of Clothing and Textiles, 35(6), 670677.

Lee, S. H., Song, W. S., \& Kim, H. R. (2009). Cutinase treatment of cotton fabrics. Fibers and Polymers, 10 (6), 802-806.

Mayumi, D., Akutsu-Shigeno, Y., Uchiyama, H., Nomura, N., \& Nakajima-Kambe, T. (2008). Identification and characterization of novel poly (DL-lactic acid) depolymerases from metagenome. Applied Microbiology and Biotechnology, 79(5), 743-750.

Oksman, K., Skrifvars, M., \& Selin, J. F. (2003). Natural fibres as reinforcement in polylactic acid (PLA) composites. Composites Science and Technology, 63(9), 1317-1324.

Sawada, K., Urakawa, M., \& Ueda, M. (2007). Modification of polylactic acid fiber with enzymatic treatment. Textile Research Journal, 77(11), 901-905.

Scheyer, L. E., \& Chiweshe, A. (2001). Application and performance of disperse dyes on polylactic acid (PLA) fabric. AATCC Review, 7, 44-48.

Steinbüchel, A. (2002). Biopolymers: biology, chemistry, biotechnology, applications. Weinheim: Willy-VCH.

Tokiwa, Y., \& Jarerat, A. (2004). Biodegradation of poly (L-lactide). Biotechnology Letters, 26(10), 771-777.

Vertomen, M. A. M. E., Nierstrasz, V. A., van der Verr, M., \& Warmoeskerken, M. M. C. G. (2005). Enzymatic surface modification of poly (ethylene terephthalate). Journal of Biotechnology, 120(4), 376-386.

Yoon, M. Y., Kellis, J., \& Poulose, A. J. (2002). Enzymatic modification of polyester. AATCC Review, 8, 33-36. 